\title{
Anti-aging effects of casuarictin on UVB-induced CCD-986sk cell
}

\author{
You Ah Kim ${ }^{1}$ Dong Hee Kim² Young A Kim² Jae Myo Yu \\ Byoung Jun Park ${ }^{1} \cdot$ Jun Ho Son ${ }^{2}$ (D)
}

\section{UVB유도성 CCD-986sk cell에서의 Casuarictin의 항노화 효과}

\author{
김유아 $^{1} \cdot$ 김동희 $^{2} \cdot$ 김영 아 $^{2} \cdot$ 유재묘 $^{2} \cdot$ 박병준 $^{1} \cdot$ 손준호 $^{2}$
}

Received: 17 August 2016 / Accepted: 20 October 2016 / Published Online: 31 March 2017

(C) The Korean Society for Applied Biological Chemistry 2017

\begin{abstract}
To develop a new functional agent for cosmetics, we investigated the anti-aging activities in fibroblasts of casuarictin. The anti-aging effect of casuarictin in CCD-986sk cell was as follows: it inhibited ROS expression increased by Ultraviolet B and suppressed pro-collagen expression. Also, casuarictin had inhibited Matrix metalloproteinase- 1 expression. Therefore, the results suggested that casuarictin has considerable potential as a cosmetics ingredient with a anti-aging effect.
\end{abstract}

Keywords Anti-aging - Casuarictin · Matrix metalloproteinase$1 \cdot$ Pro-collagen

\section{서 론}

피부노화는 잔주름, 피부건조증, 탄력감소 등의 경미한 임상 특

Jun Ho Son $(\bowtie)$

E-mail:bio115@nikom.or.kr

${ }^{1}$ Bio Materials R\&D Center, Kolmar Korea, CBTP, Future Convergent Tech Center, 76, Yeongudanji-ro, Ochang-eup, Cheongwon-gu, Cheongjusi, Chungbuk 28116, Republic of Korea

${ }^{2}$ Traditional Korean Medicine Technology Division, R\&D Department, Applied Product Development Team, National Development Institute of Korean Medicine, 94, Hwarang ro(Gapje-dong), Gyeongsan-si, Gyeongbuk 38540 , Republic of Korea

This is an Open Access article distributed under the terms of the Creative Commons Attribution Non-Commercial License (http://creativecommons. org/licenses/by-nc/3.0/) which permits unrestricted non-commercial use, distribution, and reproduction in any medium, provided the original work is properly cited.
징을 나타내는 내인성 노화와 굵고 깊은 주름이 발생하며 잔주 름도 많이 발생하는 광노화로 나눌 수 있다(Jean 1995; Laure 와 Fisher 2002).

세포외기질(extracellular martix)의 주요 구성성분인 collagen 은 섬유아세포에 의해 합성되며, 피부의 견고성, 결합조직의 저 항력과 조직의 결합력, 세포접착, 세포 분할과 분화유도 등의 역할을 한다(Jeroma 등, 1998). 피부에 높은 농도로 존재하는 collagen은 트립신과 같은 단백질 분해효소의 작용은 받지 않으 나 collagenase에 의해 분해된다(Grant와 Alburn 1959; Demina 와 Lysenko 1996). 광노화로 인한 피부 주름은 진피의 collagen 을 포함한 결합 조직 성분을 분해하는 matrix metalloproteinases (MMPs)의 활성이 증가하여 피부 조직 내의 collagen 함량이 저 하되기 때문이며, 자외선 조사량이 증가할수록 MMPs의 활성이 증가하는 것으로 보고되어 있다(Park 등, 2008; So 등, 2008).

Ultraviolet B (UVB)는 피부 세포내 활성 산소를 생성하여 직접 DNA의 손상을 일으켜 항산화 방어체계의 불균형에 의한 산화적 스트레스를 유발시킨다. 또한, 활성산소종은 $\mathrm{MMPs}$ 의 활 성을 증가시켜 결합조직성분의 분해, 절단 및 비정상적인 교차 결합에 의하여 주름을 생성시킨다(Afaq 등, 2007; Park과 Lee 2008). 즉 자외선에 의한 활성산소종은 피부 세포 내 여러 가 지 신호 전달체계를 활성화시킴으로서 $\mathrm{MMPs}$ 의 증가를 가져오 며 이는 collagen의 생성과 탄력섬유의 합성을 감소시켜 주름을 생성하게 되는 피부노화의 주된 원인임을 알 수 있다(Berneburg 등 2000).

Casuarictin은 가수분해성 tannin의 한 종류인 ellagitannin monomer로 Casuarina과 Stachyurus 종 식물에 존재한다고 알려 져 있다(Okuda 등, 1983). 구조적으로 2개의 hexahydroxydiphenic acid와 1 개의 gallic acid unit이 glucose molecule에 연결되어 있는 형태로 $\mathrm{pH}$ 8의 buffer 하에서 가수분해되어 많은 양의 ellagic acid를 생성한다고 보고되었다(Daniel 등, 1991). 현재까 지 알려진 Casuarictin의 효능은 항암(Miyamoto 등, 1993), 항 
염(Ishii 등, 1999), 항산화(Kahkonen 등, 2012) 등이 있다. Casuarictin을 포함하는 ellagitannins은 1,2,3,4,6-pentagalloyl glucose의 galloyl groups의 산화에 의해 주로 생성되는 polyphenol의 부류를 말한다. 이는 일부 과일류와 pomegranates, black raspberries, raspberries, strawberries, walnuts 및 almonds 와 같은 nuts와 seeds에 주로 존재하며(Amakura 등, 2000), 항 암, 항염, 항산화 효과를 가지는 것으로 보고 되어있다(Lipiñska 등, 2014). 관절염유도동물 모델에서 ellagitannin이 풍부한 red raspberries 추출물이 우수한 항염증효과를 가지는 것으로 보고 되었으며(Jean-Gilles 등, 2012), 용안씨 추출물(longan seed extacts)의 ellagitannins 계열물질은 미백효과가 있는 것이 알려 져 있다(Rangkadiloka 등, 2007). 지금까지 ellagitannin계 물질 에 대한 다양한 효능에 대해 연구가 진행되었으나 casuarictin에 대한 개별연구는 부족한 실정이며 특히 항암, 항염, 항산화 이 외의 효능에 대한 연구는 거의 이루어지지 않고 있는 실정이 다. 따라서, 본 실험에서는 복분자 씨앗 추출물로부터 분리된 casuarictin을 이용하여 기존에 밝혀지지 않은 섬유아세포내에서 의 항노화 효과를 확인하여 기능성 화장품 소재로의 이용 가능 성을 확인하고자 하였다.

\section{재료 및 방법}

\section{실험재료 및 기기}

세포 독성 실험 및 배양을 위한 3-[4,5-dimethylthiazol-2-yl]2,5-diphenyl-tetrazolium bromide (MTT)는 Sigma-Aldrich ( $\mathrm{St}$ Louis, MO, USA) 의 제품을 사용하였으며 Dulbeco's modified Eagle's medium (DMEM), fetal bovine serum (FBS) 및 Antibiotic-Antimyotic (100X)는 Gibco (Grand Island, NY, USA) 제품을 사용하였다. 유효성 평가를 위한 Matrix metalloproteinase-1 (MMP-1), Pro-COL1A1, $\beta$-actin 항체는 Santa Cruz Biotechnology (Santa Cruz, CA, USA)에서 구입 하여 사용하였으며, MMP-1, Pro-collagen kit는 각각 Abcam (Cambridge, MA, USA), TaKaRa (Shiga, Japan)에서 구입하여 사용하였다. 본 실험에 사용된 microplate reader 장비는 Spectrostar Nano (BGM LabTech, Ortenberg, Germany)를 사 용하였으며, Chemi-Doc은 LAS4000 (Fuji Film, Tokyo, Japan) 제품을 사용하였다.

\section{세포배양}

American Type Culture Collection (ATCC; Manassas, VA, USA) 에서 구매한 CCD-986sk (Human fibroblast) 세포를 $10 \%$ $\mathrm{FBS}, 5 \%$ antibiotic-antimyotic을 첨가한 $\mathrm{DMEM}$ 으로 배양기에 서 $37^{\circ} \mathrm{C}, 5 \% \mathrm{CO}_{2}$ 조건으로 배양하였다.

\section{세포독성측정}

본 실험에서 CCD-986sk 세포에 대한 시료의 유효농도를 결정 하기 위해 세포독성측정(MTT assay)을 진행하였다. 배양된 CCD-986sk 세포를 48 well plate에 각각 $5 \times 10^{4}$ cell/wells로 접종하고 24 시간 배양하였다. 동일 배지로 교체한 후 casuarictin 을 농도별 $(5,10,25,50,100 \mu \mathrm{g} / \mathrm{mL})$ 로 희석하여 처리한 후 48시간 $\mathrm{CO}_{2}$ incubator에서 배양하였다. $5 \mathrm{mg} / \mathrm{mL}$ MTT 용액과
$10 \% \mathrm{FBS}, 5 \%$ antibiotic-antimyotic을 첨가한 $\mathrm{DMEM}$ 을 혼합 하여 세포에 $10 \mu \mathrm{L}$ 씩 처리한 후 3시간 배양하였다. Demethyl sulfoxide $100 \mu \mathrm{L}$ 넣은 후, 10 분간 교반 한 후 microplate reader 로 $540 \mathrm{~nm}$ 에서 흡광도를 측정하였다.

\section{ROS (Reactive Oxygen Species) 생성량 측정}

CCD-986sk 세포를 배양한 후 96 well white plate에 $2 \times 10^{5}$ cell/wells로 접종하고 24 시간 배양하였다. 동일 배지로 교체한 후 UVB $\left(20 \mathrm{~mJ} / \mathrm{cm}^{2}\right)$ 을 조사 한 뒤, casuarictin을 $5,10,25$ $\mu \mathrm{g} / \mathrm{mL}$ 의 농도로 희석하여 처리한 후 48 시간 배양하였다. 그 후 제조사의 매뉴얼에 따라 ROS Clo $\mathrm{H}_{2} \mathrm{O}_{2}$ assay를 수행하였다.

\section{Pro-collagen 합성 및 MMP-1 발현 측정}

CCD-986sk 세포를 배양한 후 6 well plate에 $1 \times 10^{5}$ cell/wells 로 접종하고 24시간 배양하였다. 동일 배지로 교체한 후 UVB $\left(20 \mathrm{~mJ} / \mathrm{cm}^{2}\right)$ 을 조사 한 뒤, casuarictin을 $5,10,25 \mu \mathrm{g} / \mathrm{mL}$ 희 석하여 처리한 후 48시간 배양하였다. Blank와 control group은 sample의 처리없이 배양하였으며 그 후 각 well의 상등액을 이 용하여 procollagen type C-peptide assay kit와 MMP-1 hunam ELISA kit을 사용하여 실험을 진행한 뒤, microplate reader로 $450 \mathrm{~nm}$ 에서 흡광도를 측정하였다.

\section{Western Blot을 이용한 단백질의 발현 측정}

CCD-986sk 세포를 $1 \times 10^{5}$ cell/wells로 6 well plate에 분주하 여 24시간 배양한 후에 UVB $\left(20 \mathrm{~mJ} / \mathrm{cm}^{2}\right)$ 를 조사한 뒤 casuarictin을 처리하여 48시간 배양하였다. 세포를 RIPA buffer (Pierce, Rockford, IL, USA)로 용해하고 원심분리한 후 얻은 상층액을 $10 \% \mathrm{SDS}-\mathrm{PAGE}$ 를 이용해 전기영동하고 $\mathrm{PVDF}$ membrane으로 이전시켰다. $5 \%$ skim milk가 함유된 tris 완충 용액으로 1시간 blocking 한 후, Pro-collagen, MMP-1, $\beta$-actin 각각의 1 차 및 2 차 항체와 반응시켰다. 반응 후 Immobilon Western Chemiluminescent HRP substrate (Millipore, Billerica, MA, USA)를 이용하여 60 분간 반응시킨 후 Chemi-Doc을 이용 하여 현상하였다.

\section{통계처리}

본 실험의 통계처리는 SPSS 12.0 을 사용하였다. 각 실험군의 결과는 평균치와 표준편차로 나타내었으며, 각 실험군의 간의 결과는 2-표본 $\mathrm{t}$ 검정을 사용하여 분석하고 유의적인 차이가 있 는 항목에 대해서만 검정하였다. 실험군 간의 차이는 $95 \%$ 수 준 $(* p<0.05, * * p<0.01)$ 에서 유의성 있는 것으로 하였다.

\section{결과 및 고찰}

\section{세포독성 평가}

Casuarictin의 세포 독성측정과 실험에 사용될 농도 범위 결정 을 위해 MTT assay를 수행하였다. CCD-986sk 세포에 casuarictin을 $5,10,25,50,100 \mu \mathrm{g} / \mathrm{mL}$ 농도로 처리한 결과, $25 \mu \mathrm{g} / \mathrm{mL}$ 이하의 농도에서 세포생존율이 $90 \%$ 이상으로 나타 내어 CCD-986sk 세포의 생존율에 큰 영향을 나타내지 않음을 확인 할 수 있었다(Fig. 1). 


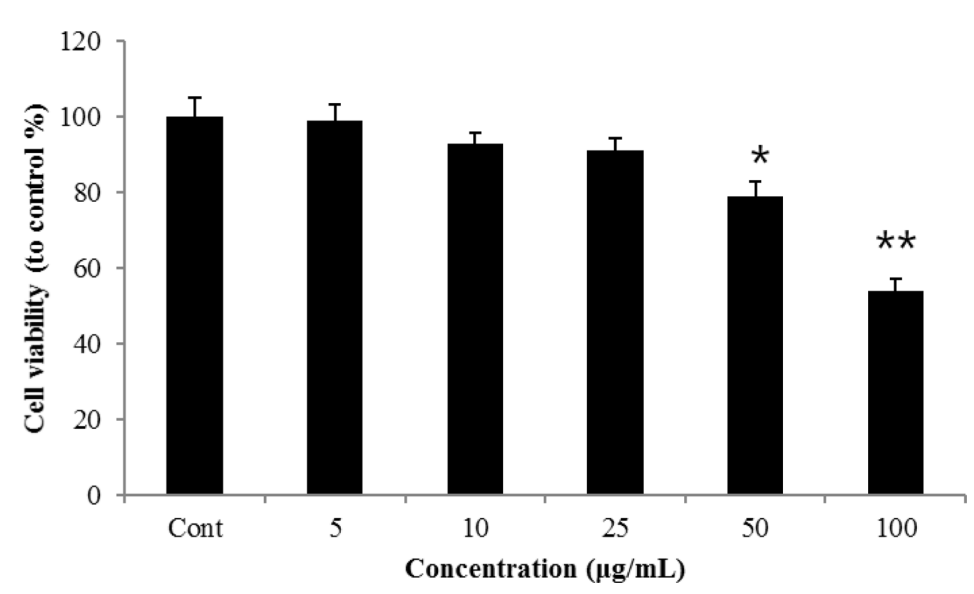

Fig. 1 Cell viability of casuarictin on CCD-986sk human fibroblast cells by MTT assay. The cells were treated various concentrations of sample. The results were expressed as the average of triplicate. ${ }^{*} p<0.05$, ${ }^{* *} p<0.01$ compared with control

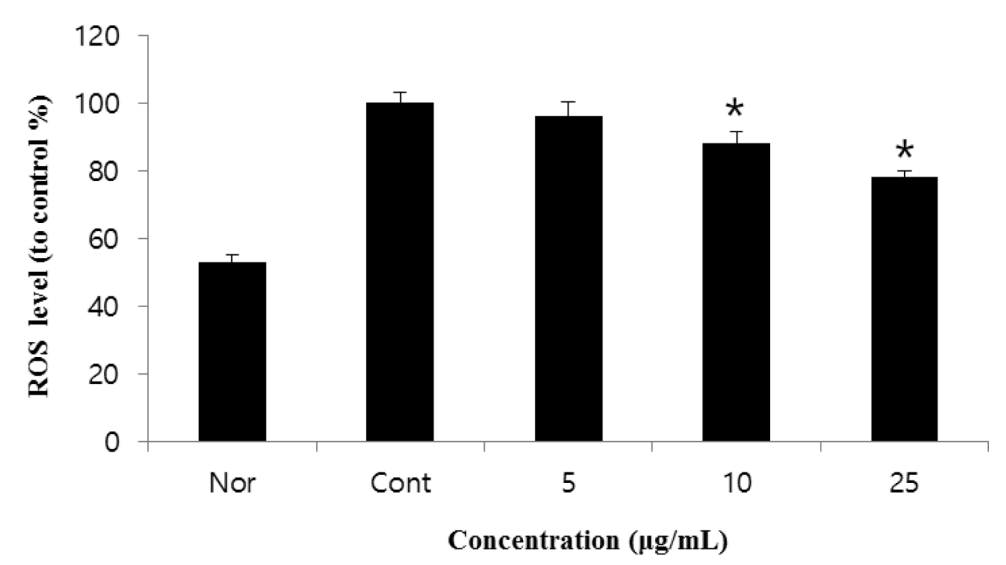

Fig. 2 Effect of casuarictin in the expression of ROS in the UVB-induced CCD-986sk human fibroblast cells. Cells were treated for $48 \mathrm{~h}$ with casuarictin $(5,10,25 \mu \mathrm{g} / \mathrm{mL})$ during UVB $\left(20 \mathrm{~mJ} / \mathrm{cm}^{2}\right)$ activation. The results were expressed as the average of triplicate. * $p<0.05$ compared with control

\section{$\operatorname{ROS}$ 생성 억제 효과}

피부에 UVB의 노출은 활성산소종 생성을 야기시키며(Fisher 등, 1997; Yoon 등, 2003; Han 등, 2013), 이때 생성되는 ROS는 피부세포 내에서의 신호전달 과정화에 영향을 미쳐 피부 주름 과 관련된 전사인자들을 활성화 시킨다(Pentland 등, 1995; Park 등, 2010). CCD-986sk 세포에서의 UVB 조사에 따른 ROS 생 성을 측정한 결과, $\mathrm{UVB}$ 로 유도된 그룹에서는 정상군에 비해 2 배 가까이 ROS 생성률이 증가하였으며, casuarictin을 농도별로 처리한 결과 농도 의존적으로 $\mathrm{ROS}$ 생성을 감소시키는 것을 확 인하였다(Fig. 2).

\section{Pro-collagen 합성 및 MMP-1 발현 측정 결과}

피부 세포의 주름과 관련된 collagens은 pro-collagen이라는 전 구물질의 형태로 합성된다. 따라서 pro-peptide의 양을 측정함으 로써 세포내에서의 collagen의 합성 정도를 파악할 수 있다 (Parfitt 등, 1987). Pro-collagen의 합성을 촉진 시킬 수 있는 소재는 탄력 있는 피부를 만들어 주는 화장품 원료로서 사용 가능성이 높다고 생각되며 이에 casuarictin을 이용하여 procollagen 합성 실험을 수행하였다. 그 결과, casuarictin은 농도
의존적으로 pro-collagen 생성을 증가 시켰으며, 특히 최고 농도 인 $25 \mu \mathrm{g} / \mathrm{mL}$ 의 농도에서는 대조군에 비해 $20 \%$ 이상의 높은 생성률을 나타내었다. 또한 MMP-1은 type collagen을 분해하는 인자로 알려져 있으므로(Talwar 등, 1995; Nagase와 Woessner $1999)$ 이 인자의 발현을 저해하는 것이 피부의 탄력유지에 효 과를 줄 수 있을 것으로 예측되는바 casuarictin의 MMP-1의 발 현 저해율 측정 실험을 수행하였 다. 그 결과, UVB로 발현된 MMP-1을 control과 비교하였을 때 casuarictin이 5, 10, 25 $\mu \mathrm{g} / \mathrm{mL}$ 의 농도에서 각각 $14,15,22 \%$ 의 발현을 저해하는 것을 확인하였다(Fig. 3).

\section{Pro-collagen 및 MMP-1 protein 측정 결과}

ELISA를 통해 Pro-collagen의 합성능과 MMP-1의 발현 저해를 정량적으로 확인 하였으며, CCD-986sk 세포에서 단백질을 추 출하여 protein level에서의 casuarictin의 효과를 확인하기 위하 여 western blot을 실행 하였다. UVB를 조사한 그룹에서는 pro-collagen 발현이 UVB를 조사하지 않은 그룹에 비해 $40 \%$ 이상 발현이 저해 되었으며, MMP-1의 발현은 UVB 조사한 그 룹이 조사하지 않은 그룹에 비해 2 배 이상 발현률이 증가하였 

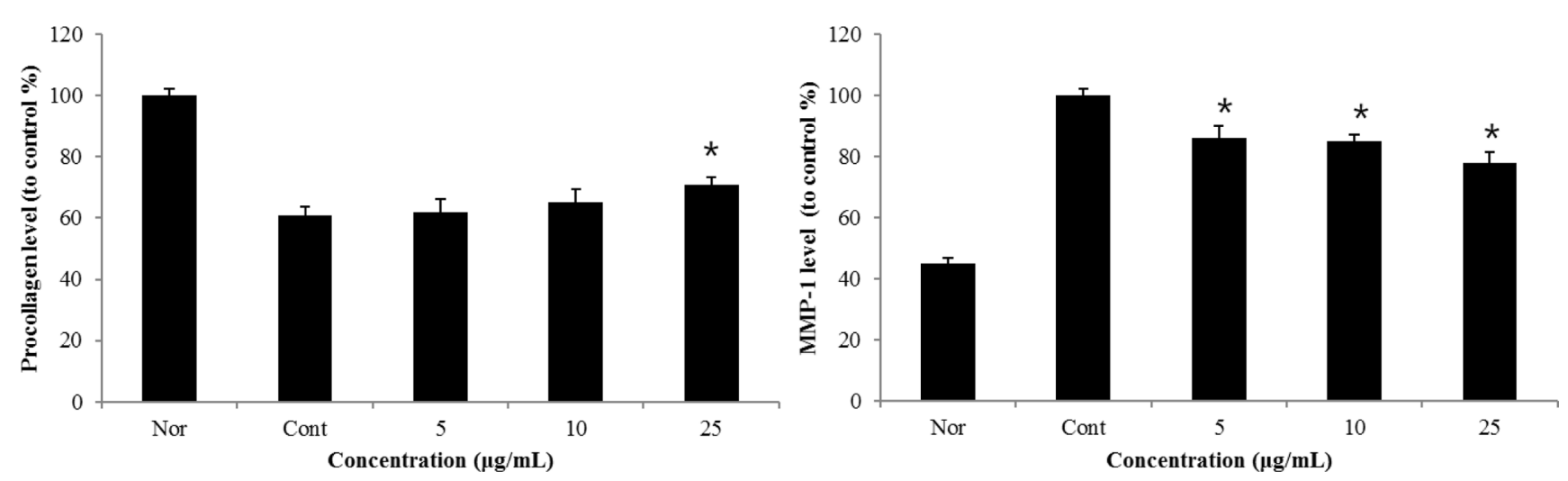

Fig. 3 Effect of casuarictin on UVB-induced pro-collagen (A) and MMP-1 (B) production in CCD-986sk human fibroblast cells. The cells were treated various concentrations of sample. The protein levels of pro-collagen and MMP-1 were determined by ELISA. The results were expressed as the average of triplicate. ${ }^{*} p<0.05$ compared with control
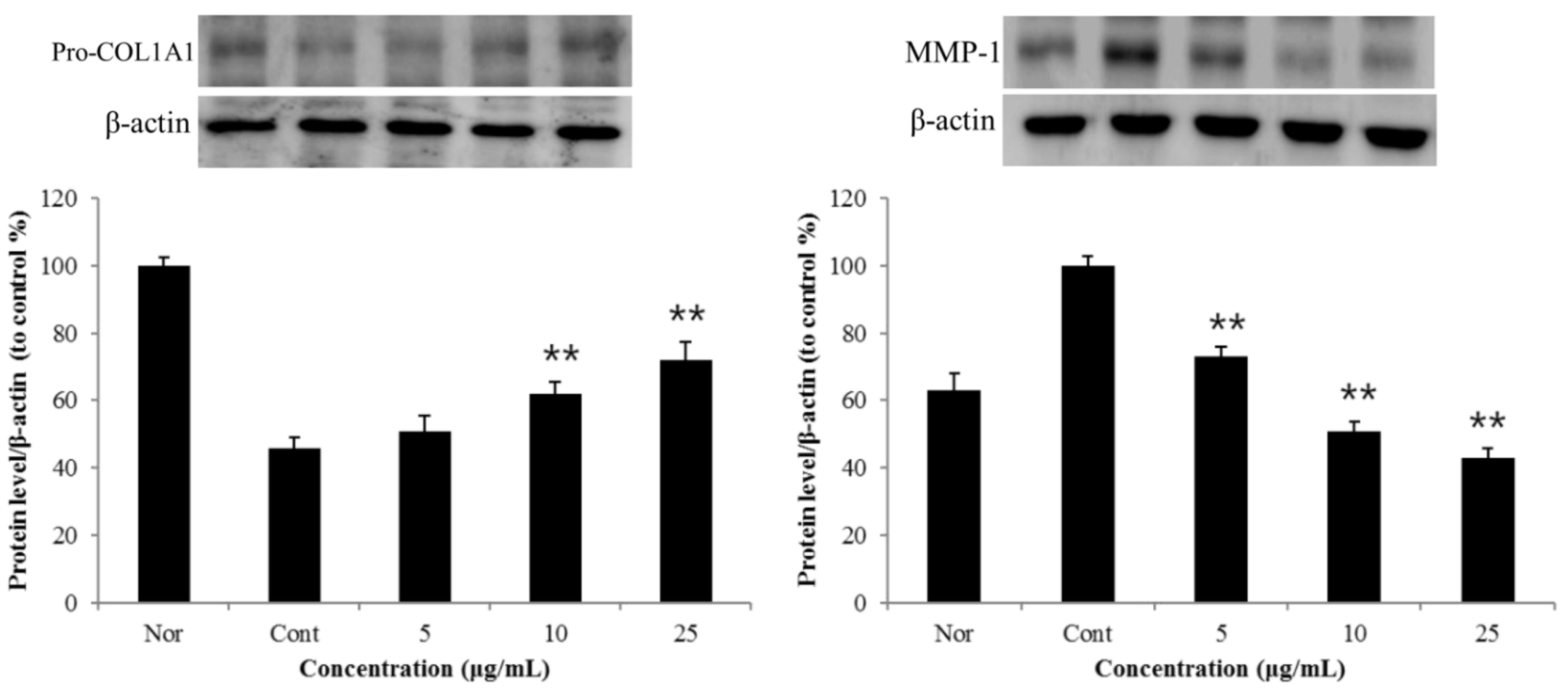

Fig. 4 Effect of casuarictin on UVB-induced pro-COL1A1 (A) and MMP-1 (B) protein expression in CCD-986sk human fibroblast cells. Cells were treated for $48 \mathrm{~h}$ with casuarictin $(5,10,25 \mu \mathrm{g} / \mathrm{mL})$ during UVB $\left(20 \mathrm{~mJ} / \mathrm{cm}^{2}\right)$ activation. Cell lysates were prepared and the protein levels of proCOL1A1 , MMP-1 and â-actin were determined by western blotting. The results were expressed as the average of triplicate samples. ${ }^{* *} p<0.01$ compared with control

다. 여기에 casuarictin을 농도별로 처리한 결과 pro-collagen protein 발현에서 대조군에 비해 $20 \%$ 이상 생성량이 증가 하 였으며, MMP-1 protein 발현이 최고 농도인 $25 \mu \mathrm{g} / \mathrm{mL}$ 에서 57 $\%$ 의 저해률을 나타내어 casuarictin의 높은 저해능을 확인하였 다(Fig. 4), 따라서 casuarictin은 CCD-986sk 세포내에서 ROS 와 같은 노화 인자의 생성을 억제함과 동시에 피부의 주요 구 성성분인 collagen의 합성 및 분해억제 효능을 나타냄으로써 항 노화 소재로서의 활용가치가 있는 것으로 판단된다.

\section{초 록}

본 연구는 새로운 기능성 화장품 소재 개발을 위해 복분자 씨
앗의 구성성분인 casuarictin을 이용하여 섬유아세포내에서의 항 노화 효과를 확인 하고자 하였다. Casuarictin의 항노화 효과를 $\mathrm{CCD}-986 \mathrm{sk}$ 세포를 이용하여 측정한 결과, casuarictin은 UVB 에 의해 증가된 ROS 발현을 억제하였으며, pro-collagen의 발 현을 증가시키고 MMP-1의 발현을 억제하는 것으로 나타났다. 이는 노화 인자인 활성산소종의 생성 억제와 주름과 밀접한 관 련이 있는 콜라겐의 합성 및 분해억제를 통해 항산화 및 주름 개선 효과가 있는 것으로 판단되며, 따라서 casuarictin은 화장 품 분야에서 항노화 소재로서의 활용가치가 있을 것으로 사료 된다.

Keywords 기질금속단백질분해효소-1 · 카수아릭틴 - 프로콜라겐 · 항노화 
감사의 글 본 연구는 보건복지부 한의약선도기술개발사업(HI13C0556) 연 구비 지원에 의해 수행 되었으며 이에 감사 드립니다.

\section{References}

Afaq F, Syed DN, Malki A, Hadi N, Sarfaraz S, Kweon MH, Khan N, Zaid MA, Mukhtar H (2007) Delphinidin, an anthocyanidin in pigmented fruits and vegetables, protects human $\mathrm{HaCaT}$ keratinocytes and mouse skin against UVB mediated oxidative stress and apoptosis. J Invest Dermatol 127: 222-232

Amakura Y, Okada M, Sumiko T, Tonogai Y (2000) High-performance liquid chromatographic determination with photodiode array detection of ellagic acid in fresh and processed fruits. J Chromato A 896: 87-93

Berneburg M, Plettenberg H, Krutmann J (2000) Photoaging of human skin. Photodermatol Photoimmunol Photomed 16: 239-244

Daniel EM, Ratnayake S, Kinstle T, Stoner GD (1991) The effects of pH and rat intestinal contents on the liberation of ellagic acid from purified and crude ellagitannins. J Nat Prod 54: 946-952

Demina NS, Lysenko SV (1996) Collagenolytic enzymes synthesized by microorganism. Mikrobiologiia 65: 293-304

Fisher GJ, Wang ZQ, Datta SC, Varani J, Kang S, Voorhees JJ (1997) Pathophysiology of premature skin aging induced by ultraviolet light. New Engl J Med 337: 1419-1428

Grant NH, Alburn HE (1959) Studies on the collagenases of Clostridium histolyticum. Arch Biochem Biophys 82: 245-255

Han SB, Kwon SS, Kong BJ, Kim KJ, Park SN (2013) Antioxidative effect and tyrosinase inhibitory activity of the unripened fruit extract of Rubus coreanus Miquel. J Soc Cosmet Sci Kor 39: 295-302

Ishii R, Saito K, Horie M, Shibano T, Kitanaka S, Amano F (1999) Inhibitory effects of hydrolyzable tannins from Melastoma dodecandrum Lour. on nitric oxide production by a murine macrophage-like cell line, RAW264.7, activated with lipopolysaccharide and interferon-gamma. Bio Pharm Bulletin 22: 647-653

Jean-Gilles D, Li L, Ma H, Yuan T, Chichester CO, Seeram NP (2012) Antiinflammatory effects of polyphenolic-enriched red raspberry extract in an antigen-induced arthritis rat model. J Agri Food Chem 60: 5755-5762

Jean LB (1995) Aging skin. Am J Med 8: S99-S103

Jeroma SP, Gabrielle L, Raul F (1998) Identification of collagen fibrils in scleroderma skin. J Invest Dermatol 90: 48-54

Kahkonen M, Kylli P, Ollilainen V, Salminen J, Heinonen M (2012) Antioxidant activity of isolated ellagitannins from red raspberries and cloudberries. J Agri Food Chem 60: 1167-1174
Laure RG, Fisher J (2002) UV-light-induced signal cascades and skin aging. Ageing Res Rev 1: 705-720

Lipiñska L, Klewicka E, Sójka M (2014) The structure, occurrence and biological activity of ellagitannins: a general review. Acta Sci Pol Technol Aliment 13: 289-299

Miyamoto K, Murayama T, Nomura M, Hatano T, Yoshida T, Furukawa T, Koshiura R, Okuda T (1993) Antitumor activity and interleukin-1 induction by tannins. Anticancer Res 13: 37-42

Nagase H, Woessner JF (1999) Matrix metalloproteinases. J Biol Chem 274: 21491-21494

Okuda T, Yoshida T, Ashida M, Yazaki K (1983) Tannins of Casuarina and Stachyurus species. I: Structures of pendunculagin, casuarictin, strictinin, casuarinin, casuariin, and stachyurin. J Chem Soc 8: 1765-1772

Parfitt AM, Simon LS, Villanueva AR, Krane SM (1987) Procollagen type I carboxy-terminal extension peptide in serum as a marker of collagen biosynthesis in bone. Correlation with iliac bone formation rates and comparison with total alkaline phosphatase. J Bone Miner Res 2: $427-$ 436

Park K, Lee JH (2008) Protective effects of resveratrol on UVB-irradiated $\mathrm{HaCaT}$ cells through attenuation of the caspase pathway. Oncol Rep 19: 413-417

Park SH, Hong YM, Choi YJ, Choi JH, Kim BK (2008) Antiwrinkle effects of Mugwort (Artemisia vulgaris) extracts on UVB-irradiated hairless mouse skin. J Korean Soc Food Sci Nutr 37: 1136-1141

Park SH, Lee KH, Han CS, Kim KH, Kim YH (2010) Inhibitory effects of Carex humilis extract on elastase activity and matrix metalloproteinase-1 expression. J Soc Cosmet Sci Kor 36: 129-136

Pentland AP, Shapiro SD, Welgus HG (1995) Agonistinduced expression of tissue inhibitor of metalloproteinases and metalloproteinases by human macrophages is regulated by endogenous prostaglandin E2 synthesis. J Invest Dermatol 104: 52-57

Rangkadiloka N, Sitthimonchaib S, Worasuttayangkurna L, Mahidolc C, Ruchirawatb M, aSatayavivad J (2007) Evaluation of free radical scavenging and antityrosinase activities of standardized longan fruit extract. Food and Chem Toxicol 45: 328-336

So SH, Lee SK, Hwang EI, Koo BS, Han GH, Lee MJ, Kim NM (2008) Mechanism of Korea red ginseng and herb extract (KTNG0345) for antiwrinkle activity. J Ginseng Res 32: 39-47

Talwar HS, Griffiths CE, Fisher GJ, Hamilton TA, Voorhees JJ (1995) Reduced type I type III procollagens in photodamaged adult human skin. J Invest Dermatol 105: 285-290

Yoon I, Wee JH, Moon JH, Ahn TH, Park KH (2003) Isolation and identification of quercetin with antioxidative activity from the fruits of Rubus coreanus Miquel. Kor J Food Sci Technol 35: 499-502 